Koubun Imai • Shoji Harada • Yoichi Kawanishi

Hirokazu Tachikawa - Takehito Okubo • Toshihito Suzuki

\title{
Association analysis of polymorphisms in the prepronociceptin gene and schizophrenia
}

\begin{abstract}
The human prepronociceptin ( $p p N o c)$ gene is located on chromosome 8p21, and several linkage studies have suggested that the susceptibility locus for schizophrenia is present in this chromosomal region. We investigated genetic variations in the promoter and coding regions of the $p p N o c$ gene to determine if there may be an association between naturally occurring mutations and the manifestation of schizophrenia. Association analyses for the variations found were conducted between 87 unrelated schizophrenic patients and 100 healthy controls. Polymorphisms were found at both the -503 locus $(\mathrm{G} / \mathrm{A})$ in the promoter region and the 353 locus (Ala118Gly) in exon 3. Additionally, rare variants were identified at the -261 locus $(\mathrm{A} / \mathrm{G})$ in the promoter region, the 515 locus $(\mathrm{G} \ln 172 \mathrm{Arg})$ in exon 3 , and the 561 locus $(\mathrm{G} / \mathrm{A})$ in the untranslated region of exon 3. A significant difference was observed in allele frequency at the 353 locus between controls and patients with continuous-course schizophrenia $(P=0.0237)$, and between patients with and without prominent negative symptoms $(P=0.0201)$. However, neither difference was significant after Bonferroni correction. In addition, there were no significant differences in genotype and allele frequencies at either the -503 or 353 locus between the control group and patients with schizophrenia. These results suggest that $p p N o c$ gene polymorphisms have no association with schizophrenia.
\end{abstract}

Key words Prepronociceptin $\cdot$ Polymorphism $\cdot$ Association analysis $\cdot$ Schizophrenia $\cdot$ Continuous course

K. Imai $(\varangle) \cdot$ Y. Kawanishi $\cdot$ H. Tachikawa $\cdot$ T. Suzuki

Department of Psychiatry, Institute of Clinical Medicine, University of Tsukuba, 1-1-1 Tennoudai, Tsukuba 305-8575, Japan

Tel. +81-298-53-3274; Fax +81-298-53-3460

e-mail: zc6k-imi@asahi-net.or.jp

S. Harada $\cdot$ T. Okubo

Institute of Community Medicine, University of Tsukuba, Tsukuba, Japan

\section{Introduction}

The opioid receptor-like 1 (ORL1) receptor is most closely related to opioid receptors in structure and function (Mollereau et al. 1994). Nociceptin (Noc), alias orphanin FQ (OFQ), consists of a 17 amino acid peptide that has recently been discovered as an endogenous agonist for ORL1 (Meunier et al. 1995; Reinscheid et al. 1995). Noc/OFQ is derived from a larger precursor protein, prepronociceptin ( $p p N o c)$, whose sequence is similar to the opioid peptide precursors, and whose mRNA is mainly expressed in the brain (Mollereau et al. 1996; Nothacker et al. 1996; Houtani et al. 1996). The human ppNoc gene is located on chromosome $8 \mathrm{p} 21$, which has previously been reported as a susceptibility locus for schizophrenia (Kendler et al. 1996; Kaufmann et al. 1998; Blouin et al. 1998).

Similarities between the effects of opioids and the symptoms of psychotic illness led to a hypothesis that the opioids are involved in the pathophysiology of schizophrenia (Wiegant et al. 1992). Noc/OFQ blocks opioid-induced supraspinal analgesia, and it may represent a functional antiopioid peptide (Mogil et al. 1996). Pain insensitivity has been reported in off-medication patients with schizophrenia (Davis et al. 1979). Noc/OFQ reduces the morphineinduced dopamine release and suppresses the metabolites released from the nucleus accumbens in rats (Di Giannuario et al. 1999). Drugs directed at the central Noc/ OFQ receptors may represent an interesting approach to the treatment of ethanol and opiate abuse (Ciccocioppo et al. 2000). ORL1 knockout mice are fertile, and show no significant anatomical defects, but they do display a significant rise in their auditory brainstem responses (ABRs) threshold (Nishi et al. 1997). Abnormal ABRs have also been reported in schizophrenic patients (Lindstrome et al. 1987). In addition, the ORL1-deficient mice exhibited increased long-term potentiation, without apparent changes in presynaptic or postsynaptic electrophysiological properties (Manabe et al. 1998). There have been no previous reports examining the association between polymorphisms in the $p p N o c$ gene and schizophrenia. 
In the present study, we investigated genetic variations in the promoter region and the coding region of the $p p N o c$ gene, and conducted a case-control study to explore an association between the $p p N o c$ gene and schizophrenia.

\section{Subjects and methods}

\section{DNA samples}

Informed written consent was obtained from subjects prior to the study according to research protocols approved by the ethics committee of Tsukuba University. A total of 87 schizophrenic patients were examined, consisting of 53 men (mean age $46.3 \pm 12.7$ years; mean age at onset $25.7 \pm 7.6$ years) and 34 women (mean age $47.3 \pm 16.3$ years; mean age at onset $27.7 \pm 10.7$ years) who matched the DSM-IV criteria for schizophrenia (American Psychiatric Association 1994). Patients were further divided into subtypes (18 paranoid, 28 disorganized, 4 catatonic, 28 residual, and 9 undifferentiated) and longitudinal courses (57 episodic, 23 continuous, 5 single episode, and 2 other or unspecified). Furthermore, 33 patients were categorized with prominent negative symptoms, defined by the DSM-IV criteria, and 39 patients with a family history in first- or second-degree relatives.

The controls consisted of 100 unrelated volunteers (30 men: mean age $32.1 \pm 11.4$ years, and 70 women: mean age $43.1 \pm 12.0$ years), who were hospital employees living in the same area as the patients. Each volunteer was interviewed by two psychiatrists in order to rule out subjects with a family history of mental illness. All of the patients and controls were ethnically Japanese.

Genomic DNA samples were prepared from whole blood collected in disodium ethylenediaminetetraacetic acid (EDTA; $3 \mathrm{mg} / \mathrm{L}$ ) according to the sodium iodide method (DNA Extractor WB Kit, Wako Pure Chemical Industries, Osaka, Japan).
Polymerase chain reaction conditions

Six sets of polymerase chain reaction (PCR) primers were used to produce DNA fragments covering exons 2 and 3 , which share an open reading frame, and the promoter region of the $p p N o c$ gene (Table 1). The nucleotidesequence numbering used in this study was based on a previous report (Xie et al. 1999; Zaveri et al. 2000) and the GenBank sequence (accession number X97370). All primers were designed from sequences available in the GenBank database (accession numbers: AF100704, X97367, and X97368). The 5'-terminus of each primer was labeled with indodicarbocyanine fluorescent dye (Amersham Pharmacia Biotech, Uppsala, Sweden) for fluorescence-based single-strand conformational polymorphism (SSCP) analysis.

The reaction mixture contained $0.5 \mathrm{ng}$ genomic DNA, $0.25 \mu \mathrm{M}$ of each primer, $0.2 \mathrm{mM}$ of each deoxynucleotide triphosphate, $10 \mathrm{mM}$ Tris- $\mathrm{HCl}(\mathrm{pH} 8.3), 50 \mathrm{mM} \mathrm{KCl}, 1.5 \mathrm{mM}$ $\mathrm{MgCl}_{2}$, and $0.5 \mathrm{U}$ of Taq DNA polymerase (HotStarTaq, QIAGEN, Hilden, Germany) in a final volume of $25 \mu \mathrm{l}$.

The amplification reaction was as follows: an initial 15 min denaturation at $95^{\circ} \mathrm{C}$, followed by 35 cycles of denaturation at $94^{\circ} \mathrm{C}$ for $30 \mathrm{~s}$, annealing at $58^{\circ} \mathrm{C}$ for $30 \mathrm{~s}$, and extension at $72^{\circ} \mathrm{C}$ for $30 \mathrm{~s}$, with a final extension step of $72^{\circ} \mathrm{C}$ for $10 \mathrm{~min}$ (GeneAmp 9600, PE Applied Biosystems, Foster city, CA, USA).

PCR products were visualized by ethidium bromide staining under UV light after electrophoresis in $2 \%$ agarose gels.

\section{SSCP analysis}

All 187 samples in our study were analyzed by using SSCP. A DNA sequencer (ALF express, Amersham Pharmacia Biotech) with a short gel plate was used to perform fluorescence-based SSCP analysis. One microliter of PCR product was mixed with $14 \mu \mathrm{l}$ of loading solution containing $99.5 \%$ deionized formamide and $0.5 \%$ blue dextran. The

Table 1. Oligonucleotide primers for amplification of the prepronociceptin gene

\begin{tabular}{|c|c|c|c|c|}
\hline Names & Primer sequences & Regions & Nucleotide position & Products (bp) \\
\hline PN-PU-F & 5'-GAAGGAGGACTTGAGGTTCAC & Promoter (upstream) & 704969-704949 & 301 \\
\hline PN-PU-R & 5'-GCCTGAGGAGTGAAGAATAGG & & 704669-704689 & \\
\hline PN-PM-F & 5'-TCCGAGTCGGTAGGAGCTTG & Promoter (midstream) & 704738-704719 & 291 \\
\hline PN-PM-R & 5'-GCTCTGCCATCAGACCTGTG & & $704448-704467$ & \\
\hline PN-PD-F & 5'-GTCCAGGTGAAGCAGGCTTG & Promoter (downstream) & $704516-704497$ & 239 \\
\hline PN-PD-R & 5'-ATGGATGCGAGGCTCGGTTC & & $704278-704297$ & \\
\hline PN-E2-F & 5'-GAGAATGGCTGTACTCATTGC & Exon 2 & $692455-692435$ & 269 \\
\hline PN-E2-R & 5'-CAGAGTCTGCTCTGGAGTAG & & $692187-692206$ & \\
\hline PN-E3U-F & 5'-GCCCTGGATTAACAGAGGTCC & Exon 3 (upstream) & $682556-682536$ & 305 \\
\hline PN-E3U-R & 5'-СTTCTGCTCCATCTCACCAGC & & $682252-682272$ & \\
\hline PN-E3D-F & 5'-TGTTCCAGGAGCAGGAAGAGC & Exon 3 (downstream) & $682313-682293$ & 291 \\
\hline PN-E3D-F'C & 5'-AGCCTGGCATGGAGGAGGC & & $682289-682271$ & 267 \\
\hline PN-E3D-F'G & 5'-AGCCTGGCATGGAGGAGG啇 & & $682289-682271$ & 267 \\
\hline PN-E3D-R & 5'-CAGCTTATTGGTGCCCAACTC & & $682023-682043$ & \\
\hline
\end{tabular}

The nucleotide sequence numbering is based on the GenBank sequence (accession number NT_007988.2) 
solution was denatured at $97^{\circ} \mathrm{C}$ for $5 \mathrm{~min}$, then immediately cooled on ice. Two microliters of single-strand PCR products were then subjected to polyacrylamide gel electrophoresis (PAGE) at $18^{\circ} \mathrm{C}$. Four types of PAGE were selected for each product as follows: $7 \%$ acrylamide (49:1, acrylamide:bisacrylamide) in $0.5 \times$ Tris-Borate-EDTA (TBE) buffer for upstream and downstream analysis of exon 3; $8 \%$ acrylamide (99:1) in $0.5 \times$ TBE buffer for exon 2 and midstream analysis of the promoter region; $10 \%$ acrylamide (99:1) in $0.5 \times$ TBE buffer for midstream analysis of the promoter region; and 7\% acrylamide (49:1) in $0.5 \times$ TBE buffer containing $10 \%$ glycerol for downstream analysis of the promoter region. The data were analyzed using the software package Fragment Manager (Amersham Pharmacia Biotech).

\section{PCR product sequencing}

PCR products showing altered band patterns under SSCP analysis were purified by agarose gel electrophoresis, followed by centrifugation to recover the DNA (Microcon tube, Millipore, Bedford, MA, USA). DNA sequences of the PCR products were directly determined using a cycle sequencing system (Dye Terminator Cycle Sequencing Ready Reaction and ABI PRISM 310 Genetic Analyzer, PE Applied Biosystems) after termination-dideoxycycle sequencing (Sequencing Reaction Kit, PE Applied Biosystems) with forward or reverse primers as indicated in Table 1.

\section{PCR using allele-specific primers}

When restriction endonuclease was not commercially available, PCR using allele-specific primers was performed to confirm the single-nucleotide polymorphisms (SNPs). Two allele-specific forward primers (PN-E3D-F'C and PNE3D-F'G) and PN-E3D-R (reverse primer) were used for an analysis of the Ala118Gly mutation at the nucleotide position $353(\mathrm{C} / \mathrm{G})$ polymorphism identified by SSCP analysis (Table 1 ). The human $\beta$-actin gene was coamplified as the internal positive control using the forward ( $\beta$-actin S: 5'-CAAGAGATGGCCACGGCTGCT) and reverse ( $\beta$-actin A: 5'-TCCTTCTGCATCCTGTCGGCA) primers (GenBank accession number AF053356).

\section{Statistical analysis}

Deviation of genotype distribution as derived from the Hardy-Weinberg equilibrium equation was calculated using the chi-square test for goodness of fit. Association analysis was performed by Fisher's exact probability test (twosided). Bonferroni correction for multiple comparisons was carried out to exclude a type I error.

Analysis of linkage disequilibrium between two given loci was performed using Associate (version 2.32) software in conjunction with linkage utility programs (Terwillinger and Otto 1994).

\section{Results}

Five variants of the ppNoc gene were identified in 187 samples by using SSCP analysis, and were confirmed further by direct sequencing of the PCR products. These included nucleotide substitutions at the -503 locus (G/A) and at the -261 locus $(\mathrm{A} / \mathrm{G})$ in the promoter region, missense mutations Ala118Gly at nucleotide position $353(\mathrm{C} / \mathrm{G})$ and Gln172Arg at the 515 locus $(\mathrm{A} / \mathrm{G})$ in the coding region of exon 3, and a nucleotide substitution at the 561 locus (G/A) in the untranslated region of exon 3. These variants did not correspond to any SNPs reported previously in the GenBank database (accession number NT_007988.2). The nucleotide positions $-503,-261,353,515$, and 561 in our study correspond to $704727,704485,682271,682108$, and 682063 , respectively, in the GenBank database.

There were no commercially available restriction enzymes for the -503 and 353 polymorphic sites. Three genotypes $(G G, G A$, and $A A)$ at the -503 locus could be distinguished clearly by SSCP analysis as well as by PCR direct sequencing (Fig. 1). Therefore, genotypes of all samples at that locus were determined by SSCP analysis. In contrast, we determined the genotypes at the 353 locus by using PCR with allele-specific primers (Fig. 2), because we could distinguish them more clearly than with SSCP analysis.

The occurrence of mutations at the $-261(\mathrm{~A} / \mathrm{G}), 515$ (A/ $\mathrm{G})$, and 561 (G/A) loci was rare in our samples. The transition from $A$ to $G$ at the -261 locus was found in only two controls and two schizophrenic patients, while the transition from $A$ to $G$ at the 515 locus was found in only one control. The transition from $\mathrm{G}$ to $\mathrm{A}$ at the 561 locus was found in only one control and one patient. All of these mutations were identified as heterozygous (Data not shown).

Distributions of all alleles at the -503 and 353 loci were consistent with the Hardy-Weinberg equilibrium equation

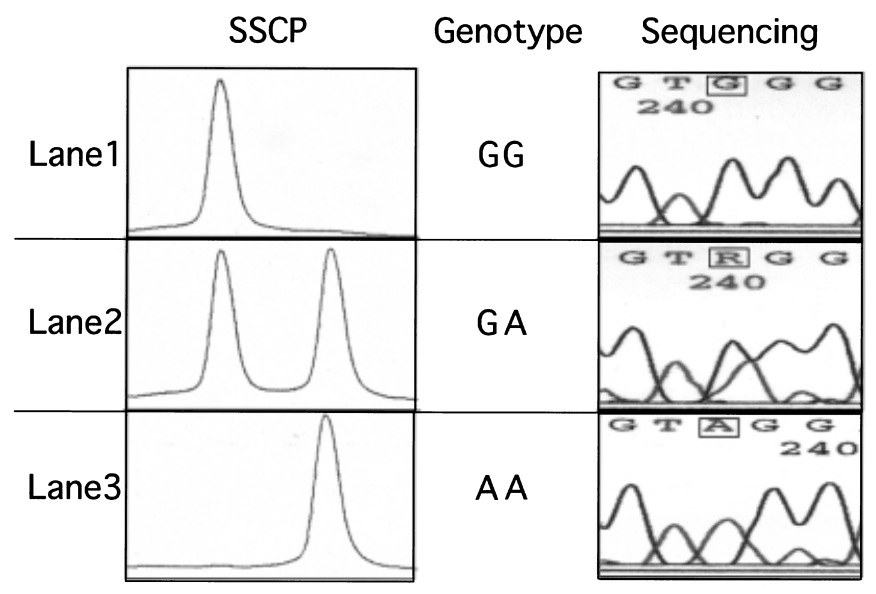

Fig. 1. Single-strand conformational polymorphism (SSCP) analysis and direct sequencing analysis of polymerase chain reaction (PCR) products generated using the PN-PU-F and PN-PU-R primer sets. The -503 (G/A) nucleotide substitution was detected by sequencing. Lanes 1,2 , and 3 indicate homozygous $(G G)$, heterozygous $(G A)$, and homozygous $(A A)$ genotypes, respectively 
Fig. 2. The 267-bp PCR product was generated using the PN-E3D$\mathrm{R}$ and $\mathrm{PN}-\mathrm{E} 3 \mathrm{D}-\mathrm{F}^{\prime} \mathrm{C}$ (in lane $C$ ) or $\mathrm{PN}-\mathrm{E} 3 \mathrm{D}-\mathrm{F}^{\prime} \mathrm{G}$ (in lane $G$ ) primer sets. The 370-bp PCR product was coamplified using the human $\beta$-actin $S$ and $\beta$-actin A primer set as an internal standard. The Ala118Gly mutation at the nucleotide position $353(\mathrm{C} / \mathrm{G})$ substitution was detected by direct sequencing analysis of PCR products generated using the PNE3D-F and PN-E3D-R primer set. Shown here is the reverse sequencing. Samples 1, 2, and 3 indicate homozygous $(C C)$, heterozygous $(C G)$, and homozygous $(G G)$ genotypes, respectively
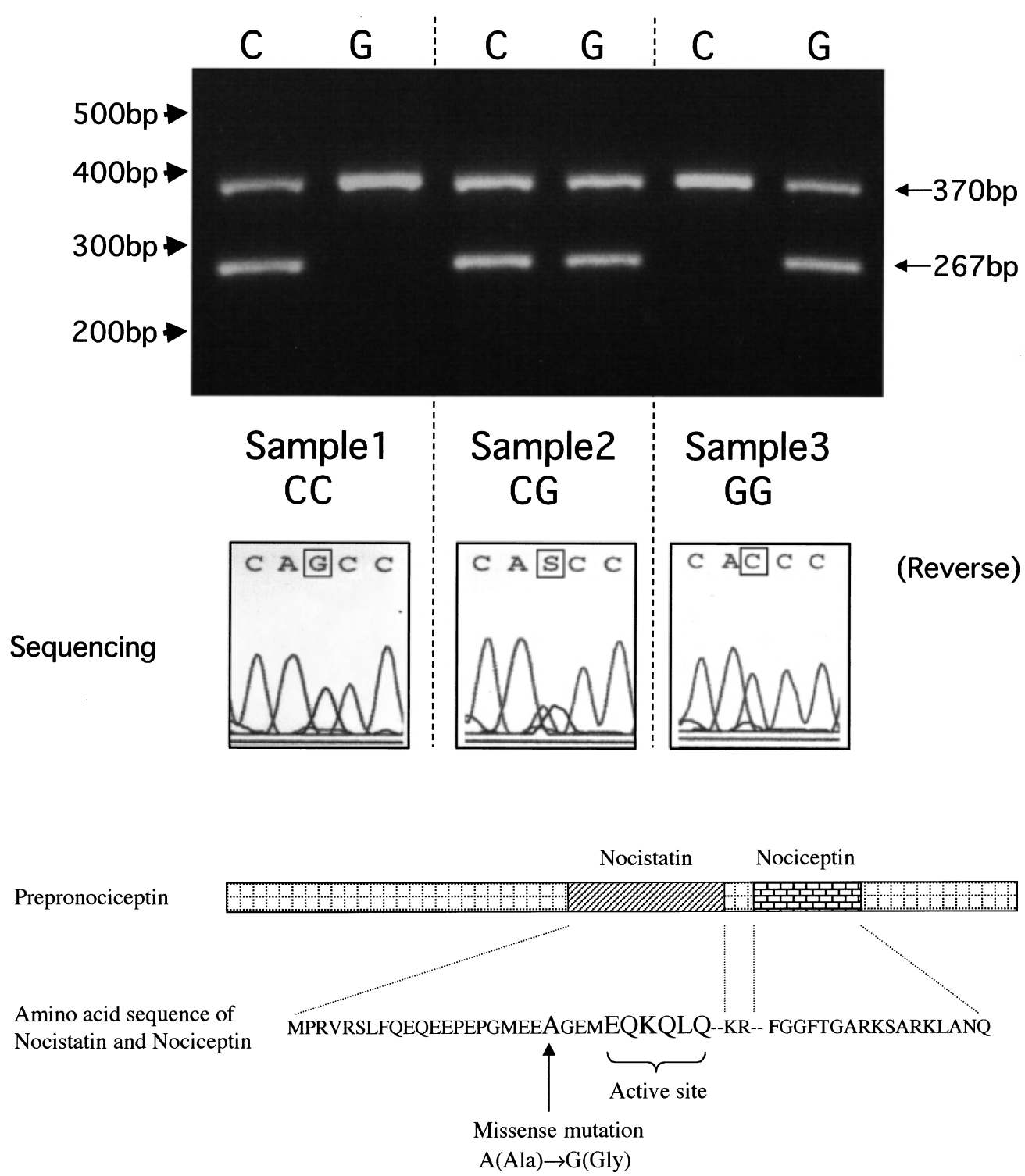

Fig. 3. The amino acid sequence of nocistatin and nociceptin/ orphanin FQ in the prepronociceptin gene. The Ala118Gly mutation site is located in the nocistatin peptide
$(P>0.05)$. One allele of single-episode-course and other or unspecified-course at the 353 locus could not be tested due to the small sample size.

No significant differences in genotype or allele frequencies at either the -503 or 353 locus were found between controls and patients (Table 2). In contrast, there was a significant difference in allele frequencies of the $353(\mathrm{C} / \mathrm{G})$ variant between controls and patients falling into the continuous-course category, as well as between controls and patients with prominent negative symptoms (Table 2). These results indicate that the frequency of the $353 \mathrm{G}$ allele in patients with continuous-course schizophrenia or patients with prominent negative symptoms was significantly higher than in controls. The difference was also significant between patients with and without continuous-course schizophrenia and between patients with and without prominent negative symptoms (Table 3). In examining the frequency of the homozygous genotype $(G G)$ versus the other genotypes with the $\mathrm{C}$ allele $(C C+C G)$ at the
353 locus, a significant difference was also found between the control group and patients with continuous-course schizophrenia $(P=0.0111$, odds ratio $[95 \%$ confidence interval]: 10.32 [1.76-60.41]), and between controls and patients with prominent negative symptoms $(P=0.0104$, odds ratio: 8.75 [1.61-47.57]). In addition, in the frequency analysis of the homozygous genotype $(G G)$ versus the other genotypes with the $A$ allele $(G A+A A)$ at the -503 locus, there was a significant difference between controls and patients with paranoid-type schizophrenia $(P=0.0236$, odds ratio: 7.64 [0.97-60.01]). However, no $P$-value differences were significant after Bonferroni correction for multiple comparisons. Furthermore, no significant differences between the controls and the patients with other subtypes, longitudinal course specifiers, or positive family history were found. A weak linkage disequilibrium was found, however, between the variants at the $-503(\mathrm{G} / \mathrm{A})$ and $353(\mathrm{C} / \mathrm{G})$ loci in 187 samples (delta value $=0.0549$, $P=0.000043)$. 


\section{Discussion}

Recently, 17 SNPs have been reported for the ppNoc gene in the GenBank database (accession number NT_007988.2). However, these polymorphic sites are located in the untranslated region (intron 1 , intron 2 , intron 3 , and the untranslated region of exon 4). In the present study, we have newly identified two nucleotide substitutions in the promoter region, two missense mutations in exon 3 , and one nucleotide substitution in the untranslated region of exon 3. It is also noteworthy that the variants at the -503 and 353 loci were highly polymorphic.

As there was no commercially available restriction enzyme for the 353 polymorphic site, we tried to identify the polymorphism by using PCR based on allele-specific primers, although this method may introduce errors. We used HotStarTaq Taq polymerase (QIAGEN) to minimize mismatching of primers, and also the $\beta$-actin gene was coamplified as an internal positive control. Indeed, three genotypes ( $C C, C G$, and $G G$ ) were distinguished clearly, as shown in Fig. 2.

We further analyzed the association between the polymorphism at the -503 locus and clinical schizophrenia, including an analysis between diagnostic subtypes and course specifiers, but found no significant differences between controls and patients. Using the TFSEARCH database program [Akiyama: http://molsun1.cbrc.aist.go.jp/research/ db/TFSEARCH.html] to look for the putative consensus sequences of transcription factor binding sites, we found that the region of the -503 locus $(\mathrm{G} / \mathrm{A})$ did not correspond to any motifs relating to transcriptional regulation. Therefore, this polymorphism may not functionally influence the transcriptional activity of the $p p N o c$ gene.

The $p p N o c$ gene produces at least two bioactive peptides, Noc/OFQ and nocistatin. Nocistatin possesses antinociceptive activity, and has been shown to play an important role in the regulation of pain transmission, as well as in learning and memory processes in the central nervous system (Okuda-Ashitaka et al. 1998; OkudaAshitaka and Ito 2000). As shown in Fig. 3, the mutation site of Ala118Gly is represented in the amino acid sequence of nocistatin; however, it is not located in the carboxylterminal hexapeptide portion (122Glu-Gln-Lys-Gln-Leu$127 \mathrm{Gln}$ ) that is important for activity (Okuda-Ashitaka et al. 1998; Okuda-Ashitaka and Ito 2000). The allele frequency of the missense mutation at the 353 locus was significantly higher in "treatment-refractory" patients with continuous-course schizophrenia and with prominent negative symptoms $(P<0.05)$. The observed $P$ values, however, were not significant after Bonferroni correction.

We assume that the major shortcoming in this analysis was the small sample size; therefore, further study using a larger population will be necessary to confirm the relationship between the $353(\mathrm{C} / \mathrm{G})$ variant and the clinical characteristics of schizophrenia. In addition, it is possible that we could have missed a variant, because the sensitivity of SSCP analysis is probably not $100 \%$ (Jordanova et al. 1997). 
Table 3. Allele frequency at the 353 locus in schizophrenic patients

\begin{tabular}{|c|c|c|c|c|c|c|c|c|}
\hline \multirow[b]{2}{*}{ Subjects (n) } & & \multicolumn{3}{|c|}{ Genotypes (\%) } & \multicolumn{4}{|c|}{ Alleles } \\
\hline & & $\mathrm{CC}$ & $\mathrm{CG}$ & GG & $\mathrm{C}$ & G & $P$ value & odds ratio \\
\hline Continuous course & (23) & $12(52)$ & $7(30)$ & $4(17)$ & 0.674 & 0.326 & 0.0323 & 2.47 [1.14-5.35] \\
\hline Other courses & (64) & $46(72)$ & $15(23)$ & $3(5)$ & 0.836 & 0.164 & & \\
\hline \multirow{2}{*}{$\begin{array}{l}\text { Prominent negative } \\
\text { symptoms }\end{array}$} & $+(33)$ & $18(55)$ & $10(30)$ & $5(15)$ & 0.697 & 0.303 & 0.0201 & 2.50 [1.18-5.28] \\
\hline & $-(54)$ & $40(74)$ & $12(22)$ & $2(4)$ & 0.852 & 0.148 & & \\
\hline
\end{tabular}

$P$ values for alleles were calculated by Fisher's exact test

Odds ratio; $95 \%$ confidence intervals are given in square brackets

In conclusion, our data suggest that the $p p N o c$ gene polymorphisms have no association with schizophrenia or its clinical characteristics.

\section{References}

American Psychiatric Association (1994) Diagnostic and statistical manual of mental disorders, 4th edn. American Psychiatric Association, Washington, DC, pp 273-315

Blouin J-L, Dombroski BA, Nath SK, Lasseter VK, Wolyniec PS, Nestadt G, Thornquist M, Ullrich G, McGrath J, Kasch L, Lamacz M, Thomas MG, Gehrig C, Radhakrishna U, Snyder SE, Balk KG, Neufeld K, Swartz KL, DeMarchi N, Papadimitriou GN, Dikeos DG, Stefanis CN, Chakravarti A, Childs B, Housman DE, Kazazian HH, Antonarakis SE, Pulver AE (1998) Schizophrenia susceptibility loci on chromosomes 13q32 and 8p21. Nat Genet 20:70-73

Ciccocioppo R, Angeletti S, Panocka I, Massi M (2000) Nociceptin/ orphanin FQ and drugs of abuse. Peptides 21:1071-1080

Davis GC, Buchsbaum MS, van Kammen DP, Bunney WE (1979) Analgesia to pain stimuli in schizophrenics and its reversal by naltrexone. Psychiatry Res 1:61-69

Di Giannuario A, Pieretti S, Catalani A, Loizzo A (1999) Orphanin FQ reduces morphine-induced dopamine release in the nucleus accumbens: a microdialysis study in rats. Neurosci Lett 272:183-186

Houtani T, Nishi M, Takeshima H, Nukada T, Sugimoto T (1996) Structure and regional distribution of nociceptin/orphanin FQ precursor. Biochem Biophys Res Commun 219:714-719

Jordanova A, Kalaydjieva L, Savov A, Claustres M, Schwarz M, Estivill X, Angelicheva D, Haworth A, Casals T, Kremensky I (1997) SSCP analysis: a blind sensitivity trial. Hum Mutat 10:65-70

Kaufmann CA, Suarez B, Malaspina D, Pepple J, Svrakic D, Markel PD, Meyer J, Zambuto CT, Schmitt K, Matise TC, Friedman JMH, Hampe C, Lee H, Shore D, Wynne D, Faraone SV, Tsuang MT, Cloninger CR (1998) NIMH genetics initiative millennium schizophrenia consortium: linkage analysis of African-American pedigrees. Am J Med Genet 81:282-289

Kendler KS, MacLean CJ, O’Neil FA, Burke J, Murphy B, Duke F, Shinkwin R, Easter SM, Webb BT, Zhang J, Walsh D, Straub RE (1996) Evidence for a schizophrenia vulnerability locus on chromosome $8 \mathrm{p}$ in the Irish study of high-density schizophrenia families. Am J Psychiatry 153:1534-1540

Lindstrom L, Klockhoff I, Svedberg A, Bergstrom K (1987) Abnormal auditory brain-stem responses in hallucinating schizophrenic patients. Br J Psychiatry 151:9-14

Manabe T, Noda Y, Mamiya T, Katagiri H, Houtani T, Nishi M, Noda T, Takahashi T, Sugimoto T, Nabeshima T, Takeshima H (1998)
Facilitation of long-term potentiation and memory in mice lacking nociceptin receptors. Nature 394:577-581

Meunier J-C, Mollereau C, Toll L, Suaudeau C, Moisand C, Alvinerie P, Butour J-L, Guillemot J-C, Ferrara P, Monsarrat B, Mazarguil H, Vassart G, Parmentier M, Costentin J (1995) Isolation and structure of the endogenous agonist of opioid receptor-like ORL1 receptor. Nature 377:532-535

Mogil JS, Grisel JE, Reinscheid RK, Civelli O, Belknap JK, Grandy DK (1996) Orphanin FQ is a functional anti-opioid peptide. Neuroscience 75:333-337

Mollereau C, Parmentier M, Mailleux P, Butour J-L, Moisand C, Chalon P, Caput D, Vassart G, Meunier J-C (1994) ORL1, a novel member of the opioid receptor family. Cloning, functional expression and localization. FEBS Lett 341:33-38

Mollereau C, Simons M-J, Soularue P, Liners F, Vassart G, Meunier J-C, Parmentier M (1996) Structure, tissue distribution, and chromosomal localization of the prepronociceptin gene. Proc Natl Acad Sci USA 93:8666-8670

Nishi M, Houtani T, Noda Y, Mamiya T, Sato K, Doi T, Kuno J, Takeshima H, Nukada T, Nabeshima T, Yamashita T, Noda T, Sugimoto $T$ (1997) Unrestrained nociceptive response and disregulation of hearing ability in mice lacking the nociceptin/ orphaninFQ receptor. EMBO J 16:1858-1864

Nothacker H-P, Reinscheid RK, Mansour A, Henningsen RA, Ardati A, Monsma FJ, Watson SJ, Civelli O (1996) Primary structure and tissue distribution of the orphanin FQ precursor. Proc Natl Acad Sci USA 93:8677-8682

Okuda-Ashitaka E, Minami T, Tachibana S, Yoshihara Y, Nishiuchi Y, Kimura T, Ito S (1998) Nocistatin, a peptide that blocks nociceptin action in pain transmission. Nature 392:286-289

Okuda-Ashitaka E, Ito S (2000) Nocistatin: a novel neuropeptide encoded by the gene for the nociceptin/orphanin FQ precursor. Peptides 21:1101-1109

Reinscheid RK, Nothacker H-P, Bourson A, Ardati A, Henningsen RA, Bunzow JR, Grandy DK, Langen H, Monsma FJ, Civelli O (1995) Orphanin FQ: a neuropeptide that activates an opioidlike G protein-coupled receptor. Science 270:792-794

Terwillinger JD, Otto J (1994) Handbook of human genetic linkage. Johns Hopkins University Press, Baltimore

Wiegant VM, Ronken E, Kovacs G, De Wied D (1992) Endorphins and schizophrenia. In: Swaab DF, Hofman M, Mirmiran M, Ravid R, van Leeuwen FW (eds) Progress in Brain Research, Elsevier, Amsterdam, pp 433-453

Xie G-X, Ito E, Maruyama K, Suzuki Y, Sugano S, Sharma M, Pietruck C, Palmer PP (1999) The promoter region of human prepronociceptin gene and its regulation by cyclic AMP and steroid hormones. Gene 238:427-436

Zaveri NT, Green CJ, Toll L (2000) Transcriptional regulation of the human prepronociceptin gene. Biochem Biophys Res Commun 276:710-717 